\title{
The Active Compound Thymoquinone Alters Chondrogenic Differentiation of Human Mesenchymal Stem Cells via Modulation of Intracellular Signaling
}

\author{
Aktif Bileşen Timokinon Insan Mezenkimal Kök Hücrelerinin \\ Kondrojenik Farklılaşmasını Hücre Içi Sinyal Mekanizmaları \\ Aracılığıyla Değiştirir
}

\section{(D) Banu ISKENDER}

Kocaeli University Faculty of Medicine, Department of Medical Biology, Kocaeli, Turkey

\begin{abstract}
Objective: The regenerative potential of mesenchymal stem cell (MSC)like cells in the cartilage is relatively low because of the lack of innervation and vascularization. The increase in proinflammatory cytokines in cartilage damage can increase the expression of apoptotic and proinflammatory genes and the matrix degradation enzymes via nuclear factor-кB (NF$\kappa B)$. Previous evidence suggested that thymoquinone (TQ) suppresses tumor necrosis factor- $\alpha$-mediated NF-KB activation in different cancer cell lines. The suppression of the NF-KB pathway increases chondrogenic differentiation by inhibiting osteogenic differentiation in MSCs. Therefore, the current descriptive study aimed at highlighting the role of thymoquinone on the differentiation of human MSCs (hMSCs) since it is predicted that agents with known anti-inflammatory properties such as TQ have the potential to alter the chondrogenic differentiation of MSCs. Methods: In this study, the bioactive component thymoquinone, with its well-documented effects on the NF-KB signaling pathway, was used in hMSC differentiation assays. The effects of thymoquinone on hMSC differentiation and the relevant intracellular signaling pathways were determined using immunocytochemistry and western blotting for the first time. Changes in the phosphorylation status of some signaling components involved in NF-KB and mTOR signaling were also evaluated. Results: The chondrogenic differentiation potential of hMSCs treated with TQ decreased, concomitant with the decrease in the activity of NF-KB signaling pathway components. Thymoquinone triggered the suppression of NF-KB signaling, which interfered with the chondrogenic potential of hMSC, as opposed to some previous findings in the literature.

Conclusions: The results of this study are of great importance for the optimization of directed differentiation of hMSCs and hMSC-mediated cellular therapies.

Keywords: Human mesenchymal stem cells, NF-kB signalling pathway, chondrogenic differentiation, thymoquinone
\end{abstract}

\begin{abstract}
öz
Amaç: Kıkırdak yapısındaki mezenkimal kök hücre (MKH) benzeri progenitör hücrelerin rejeneratif özelliği kıkırdağın sinirsiz ve damarsız yapısı nedeniyle oldukça düşüktür. Kıkırdak hasarındaki proenflamatuvar sitokinlerin artışının, nükleer faktör-kB (NF-kB) aracılığıyla apoptotik ve pro-enflamatuvar genlerin ve matriks degradasyonunda rol alan enzimlerin ifadelerini artırdığı bilinmektedir. Timokinonun farklı kanser hücre hatlarında TNF- $\alpha$ aracılı NF-kB aktivasyonunu baskıladığı daha önceki yayınlarda gösterilmiștir. Baskılanan NF-KB'nin MKH'lerde osteojenik farklılaşmayı baskılayarak kondrojenik farkılış̧mayı artırdığı da bilinmektedir. Bu nedenle bu tanımlayıcı çalışmada timokinon gibi anti-enflamatuvar özelliği bilinen ajanların insan mezenkimal kök hücrelerinin (iMHK) kondrojenik farklılaşması üzerindeki potansiyel etkisi öngörülmektedir ve timokinonun iMKH'larının farklılaşması üzerindeki etkilerinin gösterilmesi amaçlanmaktadır.

Yöntemler: Bu çalışmada NF-kB sinyal yolağı üzerindeki etkileri iyi bilinen etken madde timokinon iMHK farklılaştırma deneylerinde kullanıımıştır. Timokinonun iMKH farkıılaşması ve ilgili sinyal yolakları üzerindeki etkileri ilk kez bu çalışma ile, immünositokimya ve Western blotlama yöntemleriyle belirlenmiştir. Yine NF-kB ve mTOR yolaklarındaki sinyal moleküllerinin fosforilasyon düzeyleri Western blotlama ile gösterilmiştir.

Bulgular: Timokinon ile muamele edilmiş iMKH'lerde kondrojenik farklılaşma etkinliğinin düştüğü ve bu farklılaşma sırasında NF-kB sinyal yolağı bileșenlerinin aktivitelerinin azaldığı belirlenmiștir. Timokinonun NF-KB sinyal yolağının baskılaması sonucunda, literatürdeki bazı yayınlardaki bulguların aksine, iMKH'lerin kondrojenik farklılaşma potansiyellerinin azaldığı belirlenmiştir.

Sonuçlar: Bu çalışmanın sonuçları iMKH'lerin yönlendirilmiş farklılaştırmasının sağlanması ve iMKH aracılı tedaviler için büyük önem taşımaktadır.

Anahtar kelimeler: İnsan mezenkimal kök hücreleri, NF-kB sinyal yolağı, kondrojenik farklılaşma, timokinon
\end{abstract}

Address for Correspondence: B. Iskender, Kocaeli University Faculty of Medicine, Department of Medical Biology, Kocaeli, Turkey

E-mail: banu.iskender@yahoo.com ORCID ID: orcid.org/0000-0001-7122-1589
Received: 14 November 2021

Accepted: 14 February 2022

Online First: 24 February 2022

\footnotetext{
Cite as: Iskender B. The Active Compound Thymoquinone Alters Chondrogenic Differentiation of Human Mesenchymal Stem Cells via Modulation of Intracellular Signaling. Medeni Med J 2022;37:1-12
}

${ }^{\circledR}$ Copyright 2022 by the Istanbul Medeniyet University / Medeniyet Medical Journal published by Galenos Publishing House.

Licenced by Creative Commons Attribution-NonCommercial 4.0 International (CC BY-NC 4.0) 


\section{INTRODUCTION}

Hyaline cartilage damage, a health problem that develops as a consequence of congenital, traumatic, or degenerative disease, can affect individuals from all age groups. The regenerative potential of adult hyaline cartilage is very low because of the lack of innervation and avascular structure of the cartilage'. Chondrocyte transplantation is not a viable solution in the treatment of diseases with cartilage degeneration because of the low cell number in the cartilage tissue, the limited proliferation capacity of chondrocytes, and the decrease in the proliferation capacity of the cells with patient's age $\mathrm{e}^{2,3}$. The efforts of finding alternative cells for cartilage tissue repair yielded positive results, particularly with mesenchymal stem cells (MSCs) derived from the bone marrow and with other adult stem cells ${ }^{4,5}$.

MSCs constitute a valuable cell population for cell-based therapy, with their ability of self-renewal and immunomodulation as well as multipotency to differentiate into mesenchymal cell types (chondrogenic, osteogenic, adipogenic) and vascular smooth muscle cells ${ }^{4}$. MSCs are characterized by a positive expression of cell surface markers (CD29, CD44, CD56, CD73, CD90, CD105, CD271, STRO-1, and MSCA-1) and a lack of expression of the hematopoietic and blood cell line markers $(C D 14, C D 34 \text {, and } C D 45)^{6}$. Cells derived from the placenta, umbilical cord, synovial fluid, synovium, skeletal muscle, and adipose tissue, which could be grown in vitro, are important candidates for autologous cell therapy?.

The most popular technique for cartilage damage repair is microperforations in the subchondral bone tissue and autologous chondrocyte transfer. MSCs derived from the blood and bone marrow reach the damaged cartilage area through the drilled holes and trigger the formation of scar tissues containing fibrous tissue, fibrous cartilage, and hyaline-like cartilage. However, the quality and stability of cartilage tissue depend on variables such as the patient's age, gender, location of the defect and surgical intervention technique ${ }^{8}$. Although with the increasing knowledge in mesenchymal stem cell biology, targeting the MSCs to the damaged tissue and enabling their subsequent attachment, proliferation and chondrogenic differentiation could be achieved, an optimised technique remains yet to be discovered'. Another problem is that the regenerative potential of MSC-like progenitor cells in the articular cartilage could not be fully evoked because of the negative regulation of the inflammatory response in the surrounding damaged tissue ${ }^{10}$.
The chondrogenic differentiation of MSCs depends on the presence of ascorbate, dexamethasone, and TGF- $\beta$ among others not in monolayer cultures but aggregate culture conditions" ${ }^{11}$. While TGF- $\beta 1$, TGF- $\beta 2$, and TGF- $\beta$ equally contribute to the chondrogenic differentiation of MSCs, BMP family members BMP-2, BMP-4, BMP-6, and BMP-7 support MSC chondrogenesis by synergistically working with TGF- $\beta^{12,13}$. The undifferentiated MSCs produce collagen type I, hyaluronan, tenascin- $C$, and fibronectin, which produce glycosaminoglycan-rich extracellular matrix components specific to the cartilage tissue from the $7^{\text {th }}$ day after being cultured with prochondrogenic medium ${ }^{14}$.

The nuclear factor- $\kappa \mathrm{B}(\mathrm{NF}-\kappa \mathrm{B})$ family transcription factors (p65) (RelA), c-Rel, RelB, p50/pl05 (NF-kBl), and $\mathrm{p} 52 / \mathrm{pl00}$ (NF-кB2) form hetero- or homodimers and regulate the expressions of target genes in the nucleus that modulate cell growth, survival, adhesion, and apoptosis ${ }^{15}$. In unstimulated cells, NF- $\mathrm{kB}$ is bound in the cytoplasm to the $I \kappa B$ protein, which keeps the $N F-\kappa B$ inactive by preventing the transfer of the NF- $\kappa B-$ I $\mathrm{K}$ complex to the nucleus ${ }^{15}$. p65 (RelA), a subunit of $N F-\kappa B$, is an essential factor for chondrocyte viability. Moreover, p65 also acts as a transcription factor that activates BMP-2 and SOX-916. SOX-9, a gene expressed by chondroprogenitor cells, is the main transcription factor inducing chondrogenic differentiation ${ }^{17}$. The role of NF- $\mathrm{KB} / \mathrm{p} 65$ in regulating SOX-9 gene expression in chondroprogenitor cells places SOX-9 into a critical position for chondrogenesis. The inflammatory cytokines interleukin-1 (IL-1) and tumor necrosis factor- $\alpha$ (TNF- $\alpha$ ) decrease cartilage tissue-specific extracellular matrix production and decrease SOX9 expression in chondrocytes, thereby reducing chondrocyte-specific gene expressions such as collagen type II, type IX, type XI, and aggrecan ${ }^{18}$. Using an $1 \kappa B$ degradation inhibitor (PDTC: pyrrolidine dithiocarbamate) in primary chondrocyte cultures changed the response to IL-1 and TNF- $\alpha$ stimulation and decreased SOX-9 gene expression ${ }^{18,19}$, indicating that the cellular response to TNF- $\alpha$ and IL-1 stimuli is mediated by NF-KB. The inhibitory properties of IL-1 and TNF- $\alpha$ on chondrogenic differentiation, which are largely produced by synovial cells, have been associated with the destruction of cartilage tissues in lesions in osteoarthritis and rheumatoid arthritis. Although IL- 1 and TNF- $\alpha$ increase the metalloproteinase gene expression by activating AP-1 and NF-KB signaling, by which mechanism they inhibit, the chondrogenic phenotype has not been fully understood yet ${ }^{20}$. The chondrogenesis-inducing feature of NF- $\mathrm{KB} / \mathrm{p} 65$ has been demonstrated in the growth plate. A previous study 
reported that the increased expression of NF- $\mathrm{KB}$ subunit p65 also increased the expression and activity of BMP-2 in growth plate chondrocytes; thus, the rate of chondrocyte proliferation increased while apoptosis decreased ${ }^{16}$. $\mathrm{NF}-\kappa \mathrm{B}$ has been implicated as an intracellular signaling molecule mediating the effects of growth hormone on chondrogenesis and the production of IGF-1 and BMP-2 in growth plate chondrocytes ${ }^{21}$. In MSCs, NF-KB inhibited chondrogenic and myogenic differentiations by destabilizing SOX-9 and MyoD after their transcription. The ACTACAG motif that is repeated many times in the coding mRNA regions of both MyoD and SOX-9 genes and conserved in different organisms has been deemed important in NF-kB-mediated gene suppression ${ }^{22}$.

In human MSCs (hMSCs), a NAD (+)-dependent deacetylase sirtuin-1 forms a complex with NF-KB and inhibits downstream signaling by causing its deacetylation thereby increasing MSC chondrogenesis ${ }^{23}$. Additionally, curcumin suppresses IL-1 $\beta$-mediated NF- $\kappa B$ activation, increases collagen type II, cartilage-specific proteoglycan expression, and supports chondrogenic differentiation by suppressing the apoptotic mechanism ${ }^{10}$. In this study, we hypothesized that the active compound thymoquinone (TQ), which inhibits the DNA-binding affinity of $N F-\kappa B$, may exert significant effects on MSC differentiation by regulating the NF- $\mathrm{BB}$ signaling pathway ${ }^{24}$. Previous studies provided evidence for TQmediated regulation of NF- $\mathrm{KB}$ signaling in various cancer cell lines, which contributes to the cellular responses such as cell survival, proliferation, migration, inflammation, angiogenesis, and apoptosis ${ }^{25}$. The current study aimed to highlight the obscure link between the intracellular signaling events that are modulated directly by TQ and hMSC differentiation. Although previous literature provided evidence for NF-KB signaling and hMSC chondrogenesis by using different active compounds, the results remained contradictory and failed to provide a universal mechanism that underlies hMSC differentiation. Thus, within the scope of this descriptive study, the effects of TQ on hMSC differentiation, particularly on chondrogenic differentiation, were determined for the first time using differentiation protocols, and the changes in hMSC behavior were observed as changes in intracellular signaling pathways, including NF-KB and mammalian target of rapamycin (mTOR).

\section{MATERIALS and METHODS}

\section{Cell Culture}

Adipose tissue-derived MSCs from 3 different sources were obtained from Erciyes University Betul-Ziya Eren Genome and Stem Cell Centre (Kayseri, Turkey) and seeded them onto culture flasks with a density of $1.66 \times 10^{5} / \mathrm{cm}^{2}$. The cells were cultured in DMEM low glucose medium (Biological Industries) supplemented with 10\% FBS (Biochrom), 1\% L-glutamine, and $1 \%$ penicillin-streptomycin (Thermo Fisher Scientific) and incubated them at $37^{\circ} \mathrm{C}$ and $5 \% \mathrm{CO}_{2}$.

\section{Differentiation Assays}

Adipogenic, chondrogenic and osteogenic differentiation protocols were performed according to the manufacturer's instructions (R\&D Systems). MSCs were pre-treated with TQ at a concentration of $5 \mu \mathrm{M}$ for 10 days before conducting the differentiation protocols. The TQ dose was selected to ensure negligible cell death that would still allow scalable hMSC culture under differentiation-inducing conditions in long-term culture (at least 21 days). To evaluate the effect of the NF$\kappa \mathrm{B}$ signaling pathway on hMSC differentiation, we used 2-amino-6-[2-(cyclopropylmethoxy)-6-hydroxyphenyl]4-(4-piperidinyl)-3-pyridinecarbonitrile) (ACHP), a selective inhibitor of IKK, at a concentration of $5 \mu \mathrm{M}$ during the long-term differentiation protocols (R\&D Systems).

For adipogenic differentiation, hMSCs were plated at a seeding density of $2.1 \times 10^{4} \mathrm{cells} / \mathrm{cm}^{2}$. Adipogenic induction medium containing 90\% $\alpha$-MEM, 10\% Fetal bovine Serum, $100 \mathrm{U} / \mathrm{mL}$ Penicillin, $100 \mu \mathrm{g} / \mathrm{mL}$ Streptomycin, $2 \mathrm{mM}$ L-Glutamine and adipogenic supplement comprising hydrocortisone, isobutylmethylxanthine, and indomethacin in $95 \%$ ethanol was used on $100 \%$ confluent cells. Three cycles of induction-maintenance medium was used to achieve optimal differentiation. For chondrogenic differentiation, MSCs were cultured in 15 $\mathrm{mL}$ polypropylene culture tubes to allow pellet culture; the pellets were collected after growing for 28 days in a chondrogenic differentiation medium containing $99 \%$ DMEM/F-12, 1\% ITS supplement, $100 \mathrm{U} / \mathrm{mL}$ penicillin, $100 \mu \mathrm{g} / \mathrm{mL}$ streptomycin, $2 \mathrm{mM}$ L-glutamine, and chondrogenic supplement that includes dexamethasone, ascorbate-phosphate, proline, pyruvate, and recombinant TGF- $\beta 3$. For osteogenic differentiation, we plated the MSCs at a density of $3.1 \times 10^{3} / \mathrm{cm}^{2}$; the osteogenic induction medium containing $90 \% \alpha-M E M$, $10 \%$ fetal bovine serum, $100 \mathrm{U} / \mathrm{mL}$ penicillin, $100 \mu \mathrm{g} /$ $\mathrm{mL}$ streptomycin, $2 \mathrm{mM}$ L-glutamine, and osteogenic supplement comprising dexamethasone, ascorbatephosphate, and $\beta$-glycerophosphate was replaced until the cells changed their morphology to cuboidal shape and began to delaminate from the culture plate. The differentiation protocolswere conducted on both hMSCs-1 and hMSCs-2 cell lines in triplicates for adipogenic, chondrogenic, and osteogenic differentiation. Lipid 
vacuoles in adipogenic differentiation were visualized using FABP4 staining; osteogenic differentiation was detected using osteocalcin staining of calcium deposits; chondrogenic differentiation was confirmed using safranin-O and toluidine blue staining.

\section{Cell Viability Assay}

Human MSCs were incubated in the different doses of TQ $(10,25,50$ and $100 \mu \mathrm{M})$ for $24 \mathrm{~h}$. The cell viability assay was performed on two hMSC lines in duplicates. After the incubation cells were dissociated with trypsin, stained with $0.4 \%$ trypan blue and viable cells were detected by hematocytometer.

\section{Proliferation Assay}

Human mesenchymal stem cells were plated at a density of $1 \times 104$ cells/well and treated with different doses of $\mathrm{TQ}(5,10,25$, and $50 \mu \mathrm{M})$ to evaluate the effect of TQ on MSC proliferation. Cell Proliferation Colorimetric BrdU ELISA (Roche) was used. Briefly, MSCs were grown in 96-well tissue culture microplates and labeled with $10 \mu \mathrm{M}$ BrdU. BrdU incorporated DNA was determined by measuring the absorbance values at 450 nm (Readwell Touch ELISA Plate Reader, Robonik). Cell proliferation assay was performed on two distinct hMSC lines in duplicates. Data were presented as percentages, calculated by normalizing values against untreated control cells.

\section{Immunocytochemistry}

The cells were evaluated for the expression of differentiation markers after treatment with TQ or IKK inhibitor ACHP. The cells were fixed in $4 \%$ paraformaldehyde for $2 \mathrm{~h}$. After dehydration the cells were embedded in paraffin, $5 \mu \mathrm{m}$ sections were deparaffinised, rehydrated and stained with $0.1 \%(\mathrm{w} / \mathrm{v})$ Safranin-O, Masson's Trichrome, Toluidine Blue and Hematoxylin-Eosin. Sections were blocked for $2 \mathrm{~h}$ in PBS containing $10 \%$ bovine serum albumin (BSA) and were incubated with rabbit polyclonal anti-human collagen type II antibody (ab34712) prepared as 1:100 dilution in $1 \times$ TBS with $1 \%$ BSA overnight at $4{ }^{\circ} \mathrm{C}$. Alexa Fluor 488 donkey anti-rabbit secondary antibody was used at a dilution of 1:200.

\section{Western Blotting}

Western blotting was used to determine the effects of TQ treatment of hMSCs on the components of the NF$\kappa B$ and mTOR signaling pathways. The phosphorylation status of IKK $\alpha / \beta, N F-\kappa B, I \kappa B \alpha$ and total protein amounts of IKK $\alpha, I K K \beta, I K B \alpha$, and NF-KB were detected in cell protein lysates. mTOR activity was checked by measuring the total protein amounts of mTOR, PRAS40, AKT, and phosphorylation of mTOR, RAPTOR, AKT, PDKI, GSK3 $\beta$, and PRAS40. Cells were washed with 1× PBS, then lysed with radio-immunoprecipitation assay buffer containing $1 \times$ phosphatase inhibitor and 1× EDTA-free protease inhibitor. Cell debris was removed after centrifugation and the total protein amount was detected by BCA assay. $10 \mu \mathrm{g}$ protein samples were loaded to $4-12 \%$ bistris (w/v) SDS-PAGE gels, separated at $200 \mathrm{~V}$ for $45-50$ min and transferred onto a nitrocellulose membrane. Membranes were blocked overnight at $4{ }^{\circ} \mathrm{C}$ and were probed with primary antibody solutions prepared in $1 \times$ TBS-T. Afterwards, the membranes were incubated with hydrogen peroxidase-conjugated secondary antibodies in the dark, while bands were visualized with enhanced chemiluminescence using ChemiDoc MP imaging system instrument (Bio-Rad). The signalling experiments were conducted on three different hMSC lines in duplicates. The experiment of time-dependent change after TQ treatment was also performed in duplicates. The protein expression levels were normalized to the loading control protein levels following densitometer analyses with Image J (http://rsb.info.nih.gov/ij).

\section{Statistical Analysis}

The unpaired Student's t-test was used for analysis. Data in bar graphs indicate the mean \pm standard deviation, and statistical significance is expressed as follows: ${ }^{*} p<0.05 ;{ }^{* *} p<0.01$.

\section{RESULTS}

\section{TQ Is Not Cytotoxic at Certain Doses and Does} Not Interfere with Cell Proliferation

TQ treatment induces cytotoxicity when used at higher concentrations such as $50 \mu \mathrm{M}(2.5 \pm 0.7)$ and $100 \mu \mathrm{M}(0)$. When hMSCs were treated with different concentrations of TQ ranging from 10 to $100 \mu \mathrm{M}, \mathrm{TQ}$-induced cytotoxicity was at an $\mathrm{IC}_{50}$ value of approximately $10 \mu \mathrm{M}$ with a viable cell percentage of $55.75 \%$. Considering the long period of differentiation assays, we selected the $5-\mu \mathrm{M}$ dose for pretreatment of hMSCs to establish a sustainable and scalable cell culture in the long-term differentiation experiments (Figure la). The results from the cell viability experiments were also consistent with the findings from the apoptosis assay performed with Giemsa staining that is presented as Supplementary Figure la. Cells indicate no change in cell size uniformity and preserve characteristic hMSC spindle-shaped morphology with the selected dose of TQ $(5 \mu \mathrm{M})$ compared with the control. At higher TQ concentrations, the emergence of the senescent cell 
population was marked by the acquisition of hypertrophic cell morphology (Supplementary Figure 1b).

We assessed the effects of TQ on cell proliferation using two different hMSC lines. BrdU labeling was performed on hMSCs treated with different doses of TQ $(5,10,25,50 \mu \mathrm{M})$ for $12 \mathrm{~h}$. Incorporated BrdU was detected using spectrometric measurements after $24 \mathrm{~h}$ and $48 \mathrm{~h}$. No significant change was found on proliferation after TQ treatment. Treatment with $5 \mu \mathrm{M}$ TQ did not affect the proliferation rate of hMSCs-1 significantly after $24 \mathrm{~h}$ $(p=0.27)$ or $48 \mathrm{~h}(p=0.18)$ (Figure $1 b)$.

TQ Treatment Reduced the Chondrogenic Pellet Size and Collagen II Expression

hMSCs pre-treated with TQ and allowed to differentiate in the presence of TQ did not lose their differentiation ability to adipogenic and osteogenic lineages (Figure 2). On the contrary, there was a slight increase in adipogenic differentiation. Nevertheless, the effects of TQ on adipogenic and osteogenic differentiations of hMSCs need to be further evaluated. Control hMSCs and TQ-treated hMSCs did not exhibit a difference in cellular morphology during the differentiation processes. Lipid vacuoles were visible in both groups after adipogenic induction, and osteogenic differentiation was accompanied by dense cultures, demonstrating similar cell elongation and alignment in control hMSCs and hMSCs treated with TQ (Supplementary Figure $2 a$ and $2 b$ ). When hMSCs were pre-treated with TQ and TQ treatment continued during the chondrogenic differentiation protocol, hMSCs treated with TQ formed smaller aggregates. Moreover, the aggregates exhibited weaker extracellular matrix deposition as the collagen II and proteoglycan expression decreased. On day 21 of the chondrogenic differentiation, control hMSC pellets showed stronger staining with toluidine blue and collagen II compared with the hMSC pellets treated with TQ (Figure 3).

\section{The Effects of NF-kB Signaling Pathway on hMSC Chondrogenic Differentiation}

To explain the decrease in the chondrogenic potential of hMSCs and whether this decrease is correlated to the effect of TQ on NF-KB signaling, we used a selective inhibitor of IKK, which suppresses the activation of the NF-кB pathway. One group of hMSCs was treated with a chemical inhibitor ACHP which specifically blocks the NF- $\mathrm{KB}$ signaling pathway during the chondrogenic differentiation protocol. Chondrogenic pellets formed by hMSCs treated with TQ or with ACHP were proportionally smaller than the control hMSC pellets. Proteoglycan and glycosaminoglycan content of the pellets was detected using safranin-O and toluidine blue staining, while total collagen fibers were evaluated using Masson's trichrome and collagen II antibodies. Pellets formed by hMSCs treated with TQ or ACHP demonstrated weaker staining for extracellular matrix components, highlighting the chondrogenic differentiation. Representative images of two different experiments performed on hMSCs-1 and hMSCs- 2 are shown in Figure 4 and Supplementary Figure 3. The concomitant decrease in the extracellular matrix content manifesting the chondrogenic differentiation in TQ- and ACHP-treated hMSCs suggests that TQ may have a

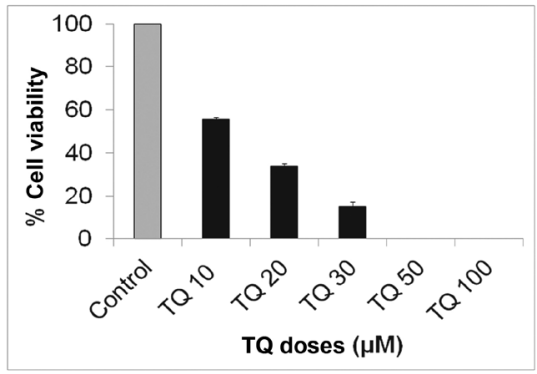

b

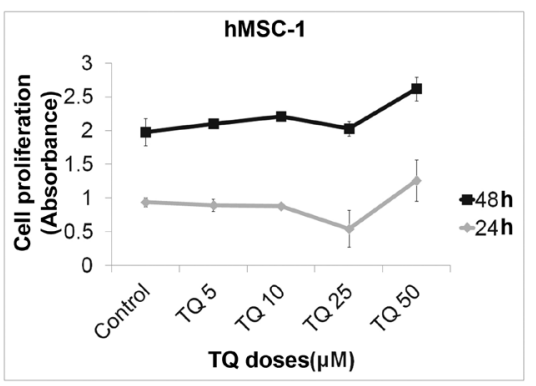

C

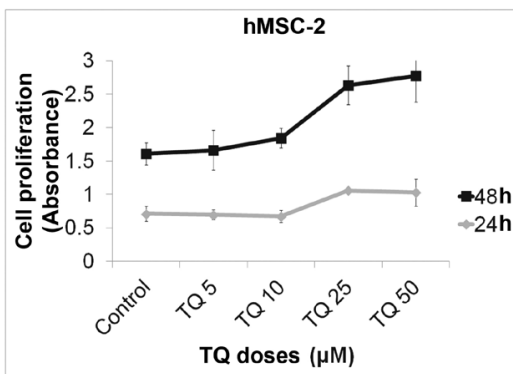

Figure 1. Detection of the effects of TQ treatment on hMSC cell viability and cell proliferation. a. Cell viability was determined using trypan blue staining after treatment with increasing doses of TQ $(10,20,30,50,100 \mu \mathrm{M})$ for $48 \mathrm{~h}$. b, c. The effects of TQ treatment on cell proliferation were shown in two different hMSC lines. hMSCs treated with different doses of TQ $(5,10,25,50 \mu \mathrm{M})$ for $12 \mathrm{~h}$ and cell proliferation was assessed using BrdU assay. Thymoquinone did not affect hMSC proliferation after $24 \mathrm{~h}$ and $48 \mathrm{~h}$.

TQ: Thymoquinone, hMSC: Human mesenchymal stem cell 
exerted its effect on hMSC chondrogenic differentiation by suppressing the NF-KB signaling.

\section{hMSC Differentiation Potential Changes After TQ-mediated Modulation of Signaling Pathways}

Since the possible effects of TQ correlated with the suppression of NF-KB signaling, we evaluated the phosphorylation statuses of components involved in

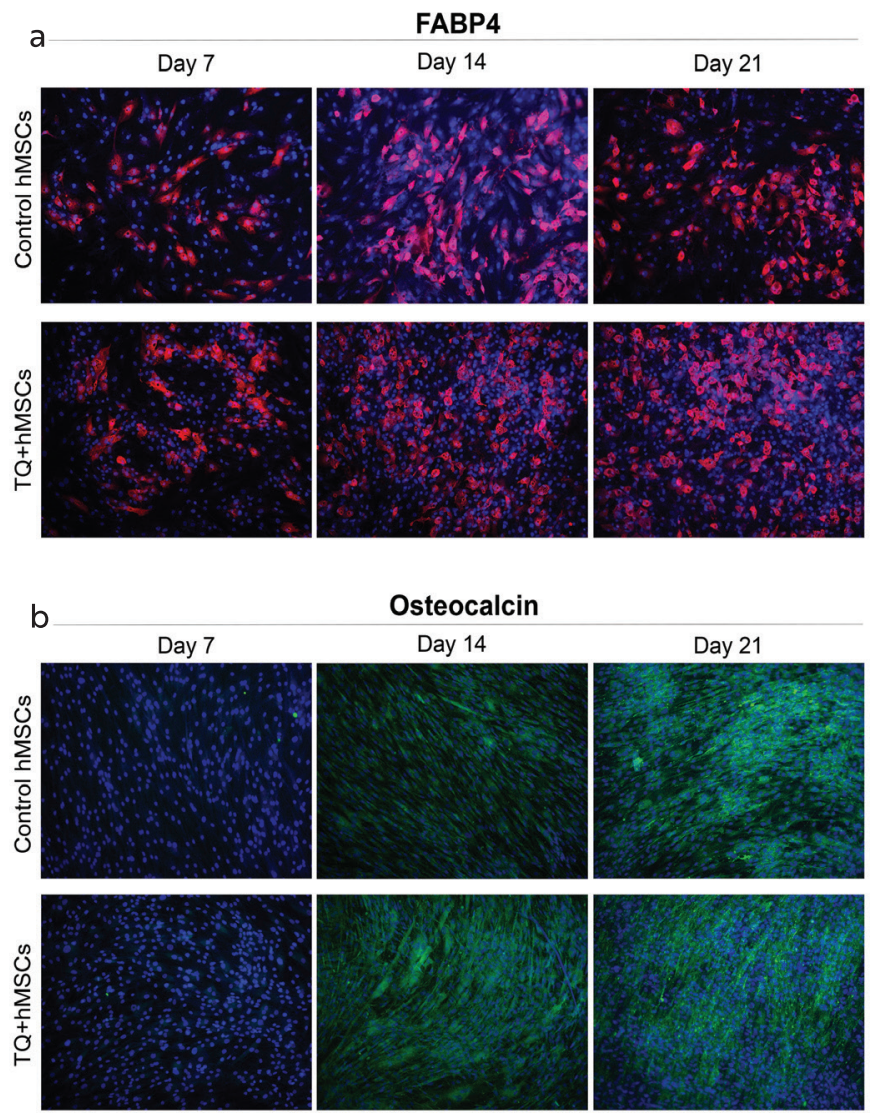

Figure 2. The effects of TQ on adipogenic and osteogenic differentiation of hMSCs. a. Control hMSCs and hMSCs treated with TQ were induced to differentiate into adipogenic lineage for 21 days; samples from days 7 , 14, and 21 were stained for adipogenic marker FABP4. hMSCs at days 14 and day 21 exhibited a slight increase in the expression of FABP4. b. Control hMSCs and hMSCs treated with TQ were induced to differentiate into the osteogenic lineage. Samples from days 7, 14, and 21 were stained with osteocalcin. No significant change was detected in osteocalcin expression in control hMSCs and hMSCs treated with TQ. Microscopy images were taken at $20 \times$ magnification.

TQ: Thymoquinone, hMSC: Human mesenchymal stem cell

NF- $\mathrm{KB}$ signaling using western blotting. The total NF$\kappa \mathrm{B}$ protein amount did not change significantly in TQtreated hMSCs, while the phosphorylation of NF-KB subunit p65 decreased in hMSC cell lines 1, 2, and 3 ( $p<0.05, p<0.05$, and $p<0.01$, respectively), compared with that in the control hMSCs (Figure $5 \mathrm{a}$ and $5 \mathrm{~b}$ ).

Since TGF- $\beta$ regulates $\beta$-catenin signaling and osteoblast differentiation in hMSCs and TQ increased the $\beta$-catenin phosphorylation in short-term treatment ${ }^{26}$, we evaluated the changes in protein levels of $\mathrm{mTOR}$, PRAS40, AKT, and $\beta$-catenin inhibitor CSK3 $\beta$ using western blotting to determine whether the increase in $\beta$-catenin phosphorylation was due to the dysregulation of PI3K/AKT/mTOR pathway. TQ treatment changed the phosphorylation of $\mathrm{PI} 3 \mathrm{~K} / \mathrm{AKT} / \mathrm{mTOR}$ signaling pathway components that regulate cytokine secretion. The total protein levels of mTOR, PRAS40, and AKT exhibited a significant change $(p<0.05$ and $p<0.05)$, while the phosphorylation of CSK3 $\beta$ significantly decreased after TQ treatment $(p<0.05)$ (Figure 6a and 6b). The decrease

\section{Collajen II}

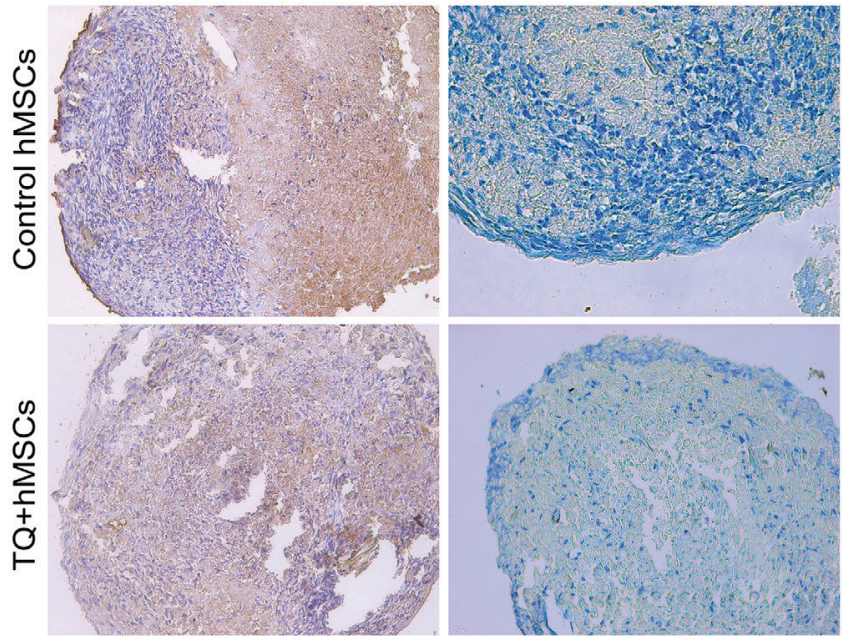

Figure 3. The effects of TQ treatment on chondrogenic differentiation of hMSCs. Control hMSCs and hMSCs treated with TQ were exposed to chondrogenic differentiation conditions for 21 days. The pellets were paraffin-embedded, sectioned, and stained with anticollagen II antibody and toluidine blue. The pellets formed by hMSCs treated with TQ exhibited weaker extracellular matrix deposition as detected by lower collagen II and proteoglycan staining than the control hMSC pellets. Microscopy images were taken at $20 \times$ magnification.

TQ: Thymoquinone, hMSC: Human mesenchymal stem cell 
in GSK3 $\beta$ phosphorylation, which inhibits $\beta$-catenin activity, may serve as evidence for the increase in the $\beta$-catenin activity in hMSCs after TQ treatment ${ }^{26}$. Changes in mTOR signaling affected adipogenesis and osteogenic differentiation, which might explain the slight changes in adipogenic differentiation of hMSCs after the suppression of NF-KB signaling with TQ treatment ${ }^{27}$.

\section{DISCUSSION}

Multipotent MSCs are found in somatic tissues and are considered as significant candidates for cell-based therapies, with their potential to differentiate into different cell lineages ${ }^{28}$. hMSC behavior and differentiation

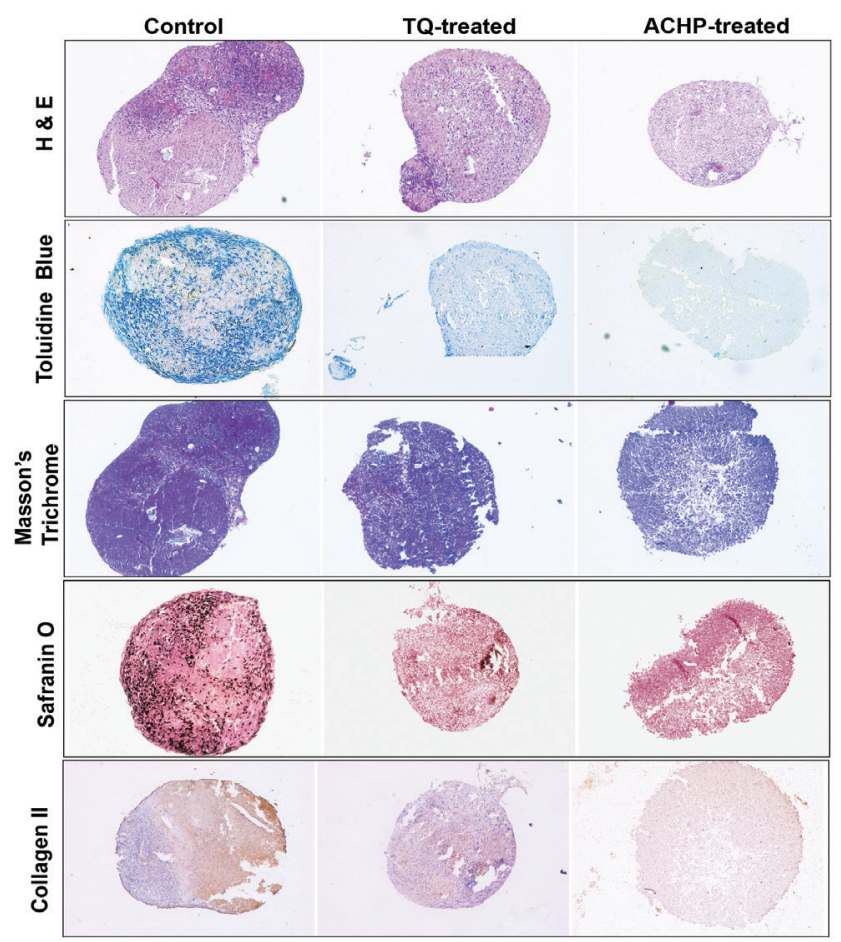

Figure 4. The effects of NF-KB signaling inhibition and TQ on chondrogenic differentiation of hMSCs. Chondrogenic differentiation of hMSCs was induced in the presence of either TQ or NF-kB inhibitor ACHP. The pellets were stained with hematoxylin-eosin, toluidine blue, Masson's trichrome, safranin- $O$, and collagen II antibodies on day 21 of differentiation. The pellet sizes were reduced; proteoglycan/glycosaminoglycan and collagen content decreased in comparison with the control in TQ- or ACHP-treated hMSC pellets. Microscopy images were taken at 10× magnification.

TQ: Thymoquinone, hMSC: Human mesenchymal stem cell, NF-кB: Nuclear factor-кB, ACHP: (2-amino-6-[2(cyclopropylmethoxy)-6-hydroxyphenyl]-4-(4-piperidinyl)3-pyridinecarbonitrile) potential may vary depending on multiple factors ${ }^{29}$. Multiple signaling pathways have been implicated in the regulation of differentiation, but the mechanisms by which hMSCs incorporate these signals to differentiate into a certain lineage have not been fully understood yet. Therefore, in this study, we sought to determine whether TQ which can change the hMSC cytokine profile, might also alter the differentiation potential of $\mathrm{hMSCs}^{30}$. This study highlights the potential link between TQ's inherent ability to modulate intracellular signaling events and hMSC differentiation with a special emphasis on chondrogenesis.

In this study, the phosphorylation of the NF- $\mathrm{KB} / \mathrm{p} 65$ subunit decreased in three different hMSC lines after TQ treatment. Pretreatment with TQ also yielded similar results with NF-KB inhibitor $A C H P$ on chondrogenic differentiation of hMSCs. This implied that the inhibition of hMSC chondrogenic differentiation may be due to the suppression of NF-KB signaling. In the literature, the effect of the NF-KB signaling pathway on the chondrogenic differentiation of MSCs is controversial.

a

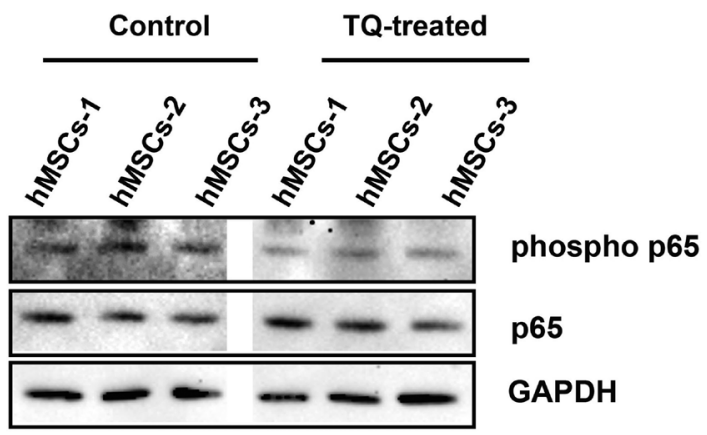

b

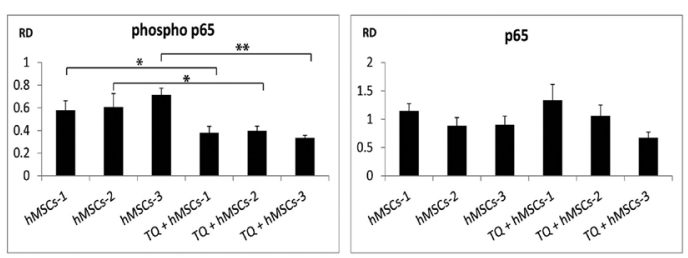

Figure 5. The effects of $\mathrm{TQ}$ on the NF-кB signaling pathway. a. Treatment with TQ reduced the phosphorylation of NF-kB subunit p65 in three different hMSC lines. b. The relative intensities of protein levels are expressed as bar graphs. Data in bar graphs indicate the mean $\pm S D$, and statistical significance is expressed as follows: ${ }^{*} p<0.05 ;{ }^{* *} p<0.01$.

TQ: Thymoquinone, hMSC: Human mesenchymal stem cell, NF-кB: Nuclear factor-кB, SD: Standard deviation 
The NF-KB signaling pathway either increased the chondrogenic differentiation of hMSCs or suppressed their chondrogenic potential ${ }^{11,23}$. This study demonstrated that TQ-mediated inhibition of $N F-\kappa B$ reduces the chondrogenic differentiation ability of MSCs. These contradictory results may be due to two possibilities: 1. Heterogeneity of hMSC lines may be responsible for different differentiation potentials after NF-kB inhibition, or 2. NF-KB signaling pathway may not be the primary signaling pathway contributing to hMSC chondrogenesis ${ }^{31}$. Moreover, some research showed that NF-KB inhibition inhibits osteogenic differentiation of $\mathrm{MSCs}^{32}$. However, in this study, while chondrogenic differentiation of hMSCs was suppressed, osteogenic differentiation did not change dramatically whereas adipogenic differentiation was increased. Therefore, the effects of NF-KB on hMSC differentiation may be cell line specific.

The PI3K/Akt/mTOR signaling pathway plays a role in hMSC differentiation. However, the effects of the signaling pathway may result in negative or positive regulation of hMSC differentiation. The mammalian target of rapamycin (mTOR) is a serine/threonine-protein kinase that is specifically involved in the regulation of cell growth/proliferation as well as transcription and translation $^{33}$. Our data suggested an increase in the activity of mTOR after TQ treatment. This may explain a slight increase in adipogenic differentiation of hMSCs after TQ treatment since our data suggested an increase in the activity of mTOR after TQ treatment, which was coupled with an increase in adipogenic differentiation. Another study also suggested that mTOR regulation is significant in adipogenic differentiation, and the downregulation of AKT-mTOR-p70S6K-PPAR could result in the suppression of adipogenic differentiation ${ }^{34}$. After TQ treatment, the total AKT protein amount increased, while AKT Ser 473 phosphorylation did not change dramatically, proving that mTOR activity was progressing independently of $\mathrm{AKT}^{35}$. Since raptor phosphorylation was not affected after TQ treatment, the increase in mTOR activity could be independent of AKT and $\mathrm{mTORCl}$ complex. Raptor is essential for mTORCl activity ${ }^{36}$, and pRAS40 acts in the regulation of $\mathrm{mTORCl}$ complex ${ }^{37}$. The fact that the activity of these components was not changed as a result of TQ treatment suggests that the activity of $\mathrm{mTORCl}$ may not be affected, but mTORC2 may be altered, which might be responsible for the slight a

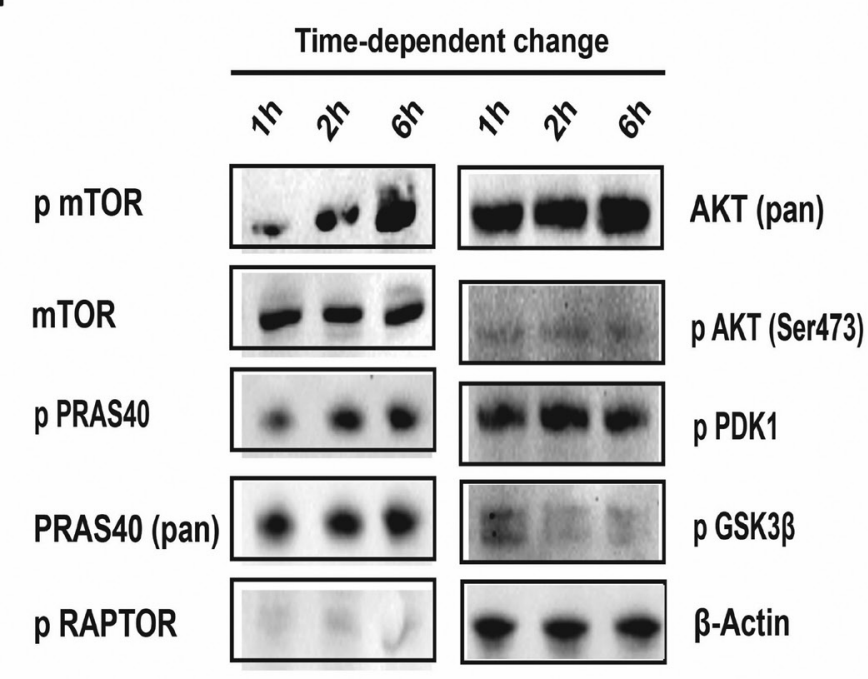

b

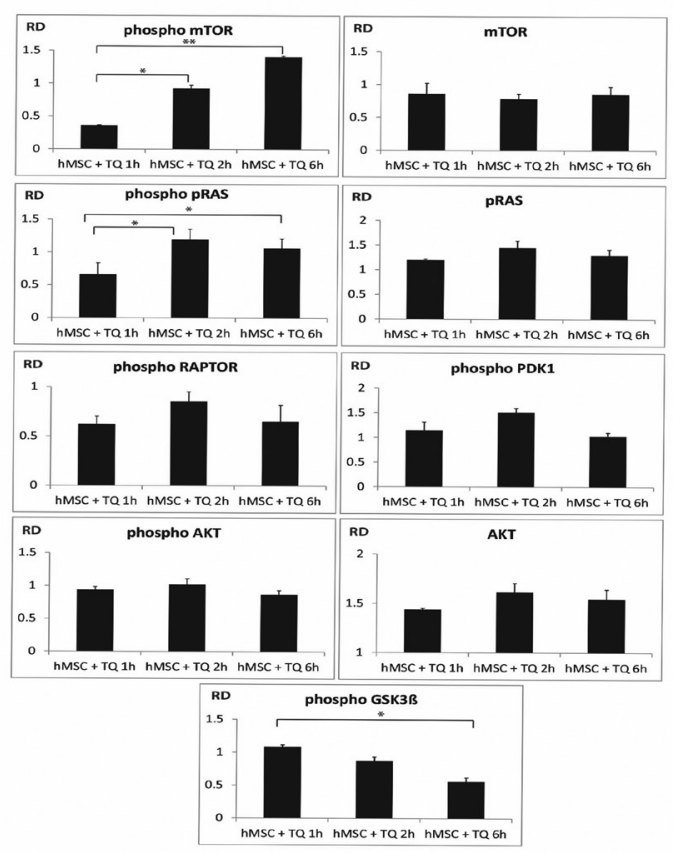

Figure 6. Time-dependent change in PI3K/AKT/mTOR signaling pathway components after TQ treatment of hMSCs. a. Thymoquinone treatment increased mTOR, AKT, PRAS40, and PDK1 phosphorylation while suppressing GSK3 $\beta$ phosphorylation in hMSCs. b. The relative intensities of protein levels are expressed as bar graphs. Data in bar graphs indicate the mean \pm SD and statistical significance is expressed as follows: ${ }^{*} p<0.05 ;{ }^{* *} p<0.01$.

TQ: Thymoquinone, hMSC: Human mesenchymal stem cell, mTOR: Mammalian target of rapamycin, SD: Standard deviation 
increase in osteocalcin deposition in TQ-treated hMSCs. Indeed, a recent study proposed that osteoblastic differentiation of MSCs is related to PI3K signaling and its downstream targets $\mathrm{mTORCl}$ and $\mathrm{mTORC2}$. When mTOR inhibitor rapamycin was used, $\mathrm{mTORCl}$ was inhibited whereas mTORC2 was activated simultaneously, which in turn, resulted in the enhancement of osteoblastic differentiation and improved calcification ${ }^{38}$. On the other hand, the expression of osteogenic markers was upregulated after the upregulation of $\mathrm{mTORCl}$ in mouse bone marrow-derived $\mathrm{MSCs}^{39}$. The contradictory results on the involvement of $\mathrm{mTORCl}$ in osteoblastic differentiation could be species-specific. Although this study provides substantial evidence for the effects of TQ on hMSC differentiation and through which pathways TQ exerts its effects on hMSC differentiation, further studies are needed for directed differentiation of MSCs and optimization of cell-based therapies.

Contrary to what has been previously demonstrated in the literature, the suppression of the NF- $\mathrm{kB}$ signaling pathway did not induce an increase in chondrogenic differentiation, which could be attributed to the heterogeneity of hMSC lines. Although short-term treatment with TQ enhanced mTOR signaling and altered the activity of downstream components in the mTOR pathway, further studies are needed to shed light on the mTOR signaling pathway and TQ's mediatory roles on hMSC differentiation.

\section{CONCLUSIONS}

Taken together, the data in this study suggest that TQ acts differently in NF- $\mathrm{B}$ regulation in distinct cell types and hMSC lines, in which TQ suppressed the NF$\kappa \mathrm{B}$ signaling. This suppression leads to an impairment in chondrogenic differentiation and slightly alters adipogenic and osteogenic differentiations of hMSCs. Since the main focus of this study was to elucidate the effects of TQ on chondrogenic differentiation based on the inferences of TQ's role on intracellular signaling previously defined on distinct cell lines, the current study has provided a deeper insight into hMSC differentiation that could be used for targeted differentiation of hMSCs and cell-based therapies.

Acknowledgments: The author wishes to thank the MSc students Ms. Esra Hizar and Ms. Aslıhan Arslanhan for assisting in cell culture and immunohistochemistry.

\section{Ethics}

Ethics Committee Approval: There were no animal experiments carried out for this article.
Informed Consent: This study does not require patient consent.

Peer-review: Externally and internally peerreviewed.

Financial Disclosure: This research was supported by the grant from the Scientific and Technological Research Council of Turkey (no. 115S042).

\section{REFERENCES}

1. Hardingham T, Tew S, Murdoch A. Tissue engineering: chondrocytes and cartilage. Arthritis Res. 2002;4(Suppl 3):63-8.

2. Dozin B, Malpeli M, Camardella L, Cancedda R, Pietrangelo A. Response of young, aged and osteoarthritic human articular chondrocytes to inflammatory cytokines: molecular and cellular aspects. Matrix Biol. 2002;21:449-59.

3. Richardson JB, Caterson B, Evans EH, Ashton BA, Roberts S. Repair of human articular cartilage after implantation of autologous chondrocytes. J Bone Joint Surg Br. 1999;81:1064-8.

4. Charbord P. Bone marrow mesenchymal stem cells: historical overview and concepts. Hum Gene Ther. 2010;21:1045-56.

5. Nogami M, Tsuno H, Koike C, et al. Isolation and characterization of human amniotic mesenchymal stem cells and their chondrogenic differentiation. Transplantation. 2012;93:1221-8.

6. Dominici M, Le Blanc K, Mueller I, et al. Minimal criteria for defining multipotent mesenchymal stromal cells. The International Society for Cellular Therapy position statement. Cytotherapy. 2006;8:315-7.

7. Yang S, Huang S, Feng C, Fu X. Umbilical cord-derived mesenchymal stem cells: strategies, challenges, and potential for cutaneous regeneration. Front Med. 2012;6:41-7.

8. Richter W. Mesenchymal stem cells and cartilage in situ regeneration. J Intern Med. 2009;266:390-405

9. Ponte AL, Marais E, Gallay N, et al. The in vitro migration capacity of human bone marrow mesenchymal stem cells: comparison of chemokine and growth factor chemotactic activities. Stem Cells. 2007; 25:1737-45.

10. Buhrmann C, Mobasheri A, Matis U, Shakibaei M. Curcumin mediated suppression of nuclear factor-kappaB promotes chondrogenic differentiation of mesenchymal stem cells in a high-density co-culture microenvironment. Arthritis Res Ther. 2010;12:127.

11. Caron MM, Emans PJ, Surtel DA, et al. Activation of NF-kappaB/ p65 facilitates early chondrogenic differentiation during endochondral ossification. PloS one. 2012;7:e33467.

12. Shen B, Wei A, Tao H, Diwan AD, Ma DD. BMP-2 enhances TGFbeta3-mediated chondrogenic differentiation of human bone marrow multipotent mesenchymal stromal cells in alginate bead culture. Tissue Eng Part A. 2009;15:1311-20.

13. Handorf AM, Li WJ. Induction of mesenchymal stem cell chondrogenesis through sequential administration of growth factors within specific temporal windows. J Cell Physiol. 2014;229:162-71.

14. Oldershaw RA, Tew SR, Russell AM, et al. Notch signaling through Jagged-1 is necessary to initiate chondrogenesis in human bone 
marrow stromal cells but must be switched off to complete chondrogenesis. Stem Cells. 2008;26:666-74.

15. Baeuerle PA, Baltimore D. NF-kappa B: ten years after. Cell. 1996;87:13-20.

16. Wu S, Flint JK, Rezvani G, De Luca F. Nuclear factor-kappaB p65 facilitates longitudinal bone growth by inducing growth plate chondrocyte proliferation and differentiation and by preventing apoptosis. J Biol Chem. 2007;282:33698-706.

17. Lefebvre V, Behringer RR, de Crombrugghe B. L-Sox5, Sox6 and Sox9 control essential steps of the chondrocyte differentiation pathway. Osteoarthritis Cartilage. 2001;9(Suppl A):69-75.

18. Murakami S, Lefebvre V, de Crombrugghe B. Potent inhibition of the master chondrogenic factor Sox9 gene by interleukin-1 and tumor necrosis factor-alpha. J Biol Chem. 2000;275:3687-92.

19. Thompson JE, Phillips RJ, Erdjument-Bromage H, Tempst P, Ghosh $\mathrm{S}$. I kappa B-beta regulates the persistent response in a biphasic activation of NF-kappa B. Cell. 1995;80:573-82.

20. Reboul P, Pelletier JP, Tardif G, Cloutier JM, Martel-Pelletier J. The new collagenase, collagenase- 3 , is expressed and synthesized by human chondrocytes but not by synoviocytes. A role in osteoarthritis. J Clin Invest. 1996;97:2011-9.

21. Wu S, Morrison A, Sun H, De Luca F. Nuclear factor-kappaB (NFkappaB) p65 interacts with Stat5b in growth plate chondrocytes and mediates the effects of growth hormone on chondrogenesis and on the expression of insulin-like growth factor-1 and bone morphogenetic protein-2. J Biol Chem. 2011;286:24726-34.

22. Sitcheran R, Cogswell PC, Baldwin AS Jr. NF-kappaB mediates inhibition of mesenchymal cell differentiation through a posttranscriptional gene silencing mechanism. Genes Dev. 2003;17:2368-73.

23. Buhrmann C, Busch F, Shayan P, Shakibaei M. Sirtuin-l (SIRTI) is required for promoting chondrogenic differentiation of mesenchymal stem cells. J Biol Chem. 2014;289:22048-62.

24. Peng L, Liu A, Shen $Y$, et al. Antitumor and anti-angiogenesis effects of thymoquinone on osteosarcoma through the NFkappaB pathway. Oncol Rep. 2013;29:571-8.

25. Sethi G, Ahn KS, Aggarwal BB. Targeting nuclear factor-kappa $B$ activation pathway by thymoquinone: role in suppression of antiapoptotic gene products and enhancement of apoptosis. Mol Cancer Res. Mol Cancer Res. 2008;6:1059-70.

26. Iskender B, Izgi K, Canatan H. Novel anti-cancer agent myrtucommulone-A and thymoquinone abrogate epithelialmesenchymal transition in cancer cells mainly through the inhibition of PI3K/AKT signalling axis. Mol Cell Biochem. 2016;416:71-84.
27. Chen $Q$ Shou P, Zheng C, et al. Fate decision of mesenchymal stem cells: adipocytes or osteoblasts? Cell Death Differ. 2016;23:1128-39.

28. Spencer ND, Gimble JM, Lopez MJ. Mesenchymal stromal cells: past, present, and future. Vet Surg. 2011;40:129-39.

29. Izgi K, Sonmez MF, Canatan H, Iskender B. Long Term Exposure to Myrtucommulone-A Changes CDI05 Expression and Differentiation Potential of Mesenchymal Stem Cells. Tissue Eng Regen Med. 2017;14:113-21.

30. Iskender B, Izgi K, Sakalar C, Canatan H. Priming hMSCs with a putative anti-cancer compound, myrtucommulone-a: a way to harness hMSC cytokine expression via modulating PI3K/Akt pathway? Tumour Biol. 2016;37:1967-81.

31. Sullivan CB, Porter RM, Evans CH, et al. TNF $\alpha$ and IL-1 $\beta$ influence the differentiation and migration of murine MSCs independently of the NF-кB pathway. Stem Cell Res Ther. 2014;5:104.

32. Cho HH, Shin KK, Kim YJ, et al. NF-kappaB activation stimulates osteogenic differentiation of mesenchymal stem cells derived from human adipose tissue by increasing TAZ expression. J Cell Physiol. 2010;223:168-77.

33. Wullschleger $\mathrm{S}$, Loewith $\mathrm{R}$, Hall MN. TOR signaling in growth and metabolism. Cell. 2006;124:471-84.

34. Rhee YH, Moon JH, Mo JH, Pham T, Chung PS. mTOR and ROS regulation by anethole on adipogenic differentiation in human mesenchymal stem cells. BMC Cell Biol. 2018;19:12.

35. Hay N, Sonenberg N. Upstream and downstream of mTOR. Genes Dev. 2004;18:1926-45.

36. Yonezawa K, Tokunaga C, Oshiro N, Yoshino K. Raptor, a binding partner of target of rapamycin. Biochem Biophys Res Commun. 2004;313:437-41.

37. Wang L, Harris TE, Roth RA, Lawrence JC Jr. PRAS40 regulates mTORCl kinase activity by functioning as a direct inhibitor of substrate binding. J Biol Chem. 2007;282:20036-44.

38. Schaub T, Gürgen $D$, Maus $D$, et al. mTORCl and mTORC2 Differentially Regulate Cell Fate Programs to Coordinate Osteoblastic Differentiation in Mesenchymal Stromal Cells. Sci Rep. 2019;9:20071.

39. Ding Y, Jiang H, Meng B, Zhu B, Yu X, Xiang G. Sweroside-mediated mTORCl hyperactivation in bone marrow mesenchymal stem cells promotes osteogenic differentiation. J Cell Biochem. 2019;120:16025-36. 
a

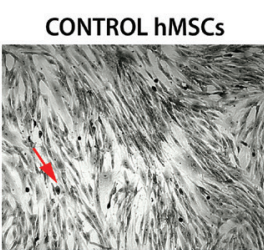

$\mathrm{hMSCs}+20 \mu \mathrm{MTQ}$

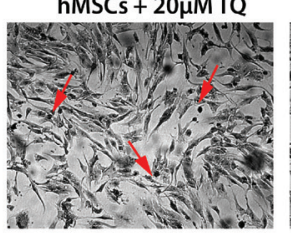

$\mathrm{hMSC}+5 \mu \mathrm{MTQ}$

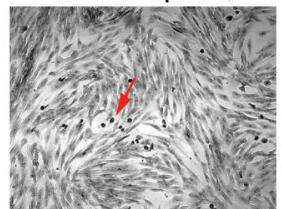

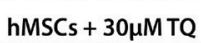

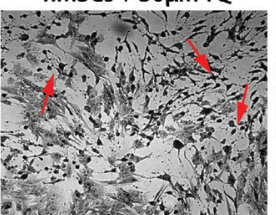

hMSCs + 10 $\mu \mathrm{MTQ}$

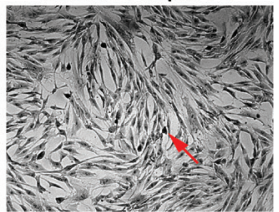

hMSCs $+50 \mu \mathrm{MTQ}$

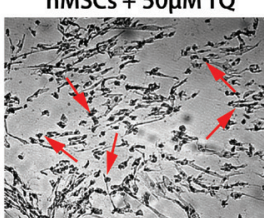

CONTROL hMSCS
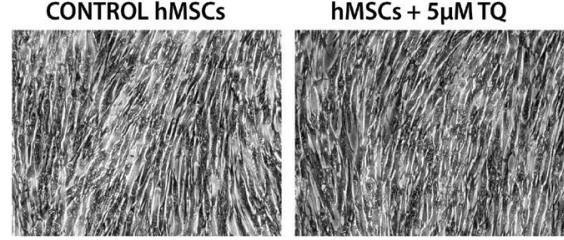

$\mathrm{hMSCs}+20 \mu \mathrm{MTQ}$

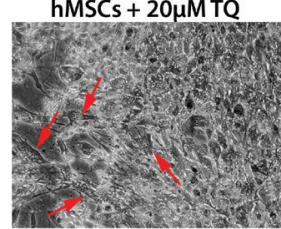

b

Supplementary Figure 1. a. Apoptosis in hMSCs after treatment with different TQ doses was assessed using Giemsa staining. hMSCs were incubated with different concentrations of TQ (5-50 $\mu \mathrm{M})$ for $24 \mathrm{~h}$, stained with 6\% Giemsa in Sorensen's phosphate buffer, and analyzed using light microscopy. Apoptotic cells with darker and condensed nuclei (as indicated by red arrows) were detected from 3 independent areas and were consistent with the results from the cell viability assays. b. Phase-contrast images of control hMSCs and hMSCs treated with different doses of TQ (5-50 $\mu$ M) at the end of the first passage. hMSCs treated with $5 \mu$ M exhibited spindle-shaped morphology similar to control hMSCs, while with the increasing doses, senescent cell populations with hypertrophic morphology have started to emerge as indicated by arrows.

TQ: Thymoquinone, hMSC: Human mesenchymal stem cell

a

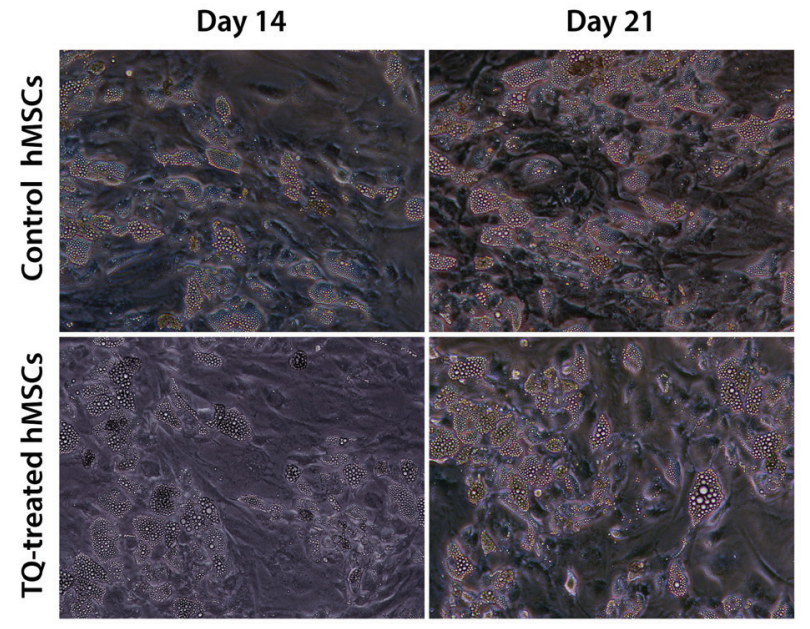

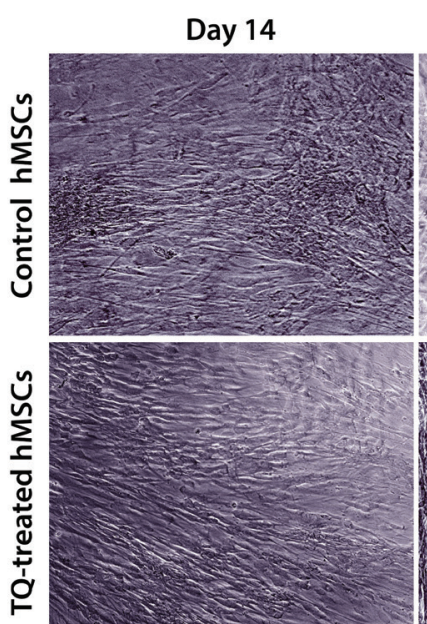

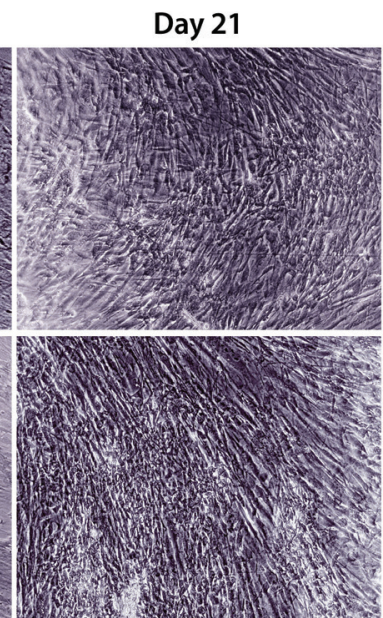

Supplementary Figure 2. a. Phase-contrast images of control hMSCs and hMSCs treated with $5 \mu$ M TQ undergoing adipogenic differentiation are taken on days 14 and 21 of differentiation. Lipid vacuoles are visible in both control and TQ-treated hMSCs. b. Phase-contrast images of control hMSCs and hMSCs treated with $5 \mu$ M TQ undergoing osteogenic differentiation are taken on days 14 and 21 of differentiation. Thymoquinone-treated cells exhibited cell morphology comparable with control hMSCs.

TQ: Thymoquinone, hMSC: Human mesenchymal stem cell 


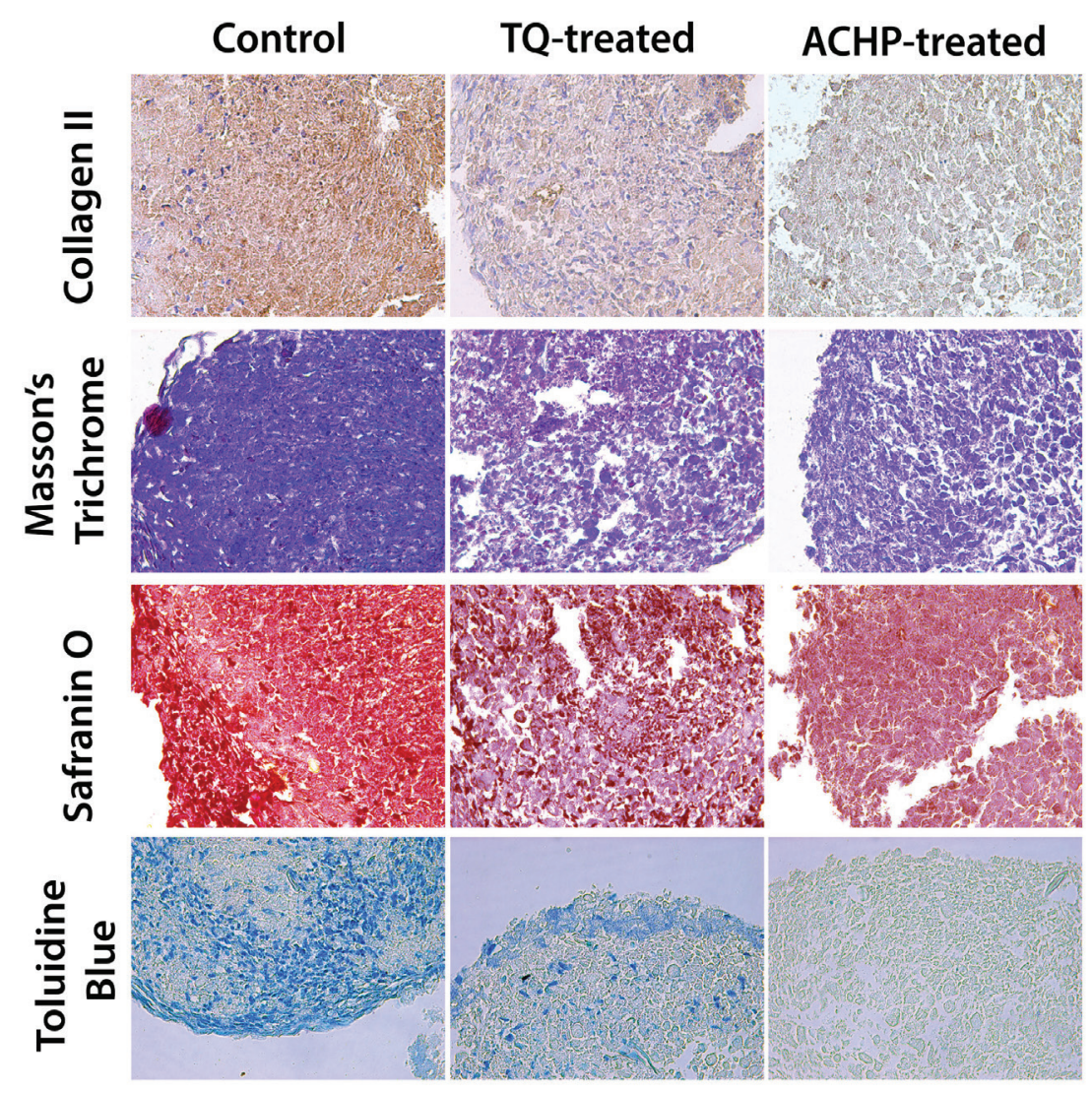

Supplementary Figure 3. Immunohistochemistry of chondrogenic pellets. The pellets were sectioned and stained with chondrogenic markers including toluidine blue, Masson's trichrome, safranin-O, and collagen II antibodies on day 21 of differentiation. Proteoglycan/glycosaminoglycan and collagen content decreased in TQ- or ACHP-treated hMSC pellets compared with those in the control. Microscopy images were taken at $40 \times$ magnification.

TQ: Thymoquinone, hMSC: Human mesenchymal stem cell, ACHP: (2-amino-6-[2-(cyclopropylmethoxy)-6-hydroxyphenyl]4-(4-piperidinyl)-3-pyridinecarbonitrile) 